\title{
Librarians' Use of Social Media for Professional Development in Nigeria
}

\author{
Uloma Doris Onuoha \\ Nigeria \\ ud_onu@yahoo.com
}

\begin{abstract}
This paper examined the use of social media for professional development by librarians in Nigeria. The study was carried out using the survey research method. The study population was made up of 1294 registered members of Nigerian Library Association Online Forum. Random sampling technique was used in selecting 297 respondents for the study. Data was collected by means of questionnaire. Findings from the study revealed that online discussion forums such as NLA online forum, online social networks such as Facebook and Wikis were mostly used for professional development, while others such as podcast and book marking tools were used minimally. Librarians were also found to learn mostly by reading through the conversations of others and joining discussion groups. Based on the findings, the study concluded that librarians in Nigeria actively seek means of professional development using social media and recommends among others, that the use of social media applications such as podcast and bookmarking tools be explored as they could also contribute to professional learning/development.
\end{abstract}

Keywords: ICT; Librarians; Nigeria; Professional development; Social media; Web 2.0

\section{Introduction}

In a world driven by technological advancement, there is need for information professionals to equip themselves with skills needed to meet the demands of the technological age. This is even more crucial for librarians in developing countries where many library schools teach traditional library curriculum and information science and technology are still at the budding stage (Njoku, 2008 as cited by Atuloma, 2010). In line with this, Majid (2004) notes that new competencies are required by information professionals in order to maintain competitive edge and work effectively in a rapidly changing environment. Professional development occurs when people seek to improve their job competencies. Macmillan Dictionary (2013) defines professional development as the process of obtaining the skills, qualifications and experience that allows you to make progress in your career. It is therefore a process whereby individuals, seek to increase their level of knowledge, refine or learn new skills, and apply these in the workplace. Several methods abound for professional development such as doing a course; taking advantage of experienced and expert practitioners in the field; reading readily available literature; attending workshops and seminars; and belonging to a professional body (Vaught, Hoy \& Buchanan, 1985; Lunenburg \& Ornstein 1996; Majid, 2004). With advancement in technology, however, librarians are also turning to social media to meet their professional needs (Martine, 2008; Ezeani, 2010; Olasina, 2011). Kaplan \& Haenlein (2010) define social media as a group of Internet-based applications that build on the ideological and technological foundations of Web 2.0. Such applications allow users to interact freely, share and discuss information using a multimedia mix of personal words, pictures, video and audio. Curtis (2011) affirms that social media appear in many forms including blogs and microblogs, forums and message boards, social networks, wikis, virtual worlds, social bookmarking and video sharing. Kaplan \& Haenlein (2010) went further to classify social media into six broad categories; blogs (e.g. twitter), collaborative projects (e.g. Wikipedia), social networking sites (e.g. Facebook), content communities (e.g. YouTube), virtual social worlds (e.g. Second Life), and virtual game worlds (e.g. World of Warcraft).

Social media applications offer boundless opportunities for users to learn while also contributing to the knowledge of others. Curtis (2011) opines that social media encourage people to create new knowledge and share it across their online communities. People are, therefore, exposed to an ever greater variety of viewpoints and ways of looking at the world. Blackwell, Sheridan, Instone, Schwartz and Kogan (2009) acknowledge that social media can be used to capture tacit knowledge, which can aid the rapid resolution of problems, by providing employees with a mechanism to quickly and efficiently access the expertise of many users. According to Gruber (2008), librarians would gain advice and expertise on issues that arise in their professional work as a result of their interactions on social media. The main aim of this study is to 
examine librarians' use of social media for professional development. In order to carry out the objective the following questions are raised:

- Which social media applications are used mostly for professional development?

- What are the strategies for learning in social media?

- To what extent are librarians satisfied with using social media for professional development?

The findings of this study would no doubt provide empirical evidence on the social media applications used by librarians in Nigeria for the purpose of professional development, while also revealing their learning strategies.

Statement of the problem: In an ever changing world where skills often become outdated, there is need for re-learning in other to cope with new challenges. Although Librarians have been known to develop themselves professionally through attendance at conferences, seminars, workshops, etc. the internet now offers additional option through social media which enables interaction among users from all parts of the globe but the extent to which librarians in Nigeria avail themselves of these applications remains unknown. It is in view of the foregoing, that the present study investigates librarians' use of social media for professional development in Nigeria.

\section{The need for professional development}

The term development broadly refers to changes in individuals over time (Feldman 1997). Professional development is defined by Reitz (2004) as "further study undertaken during employment by a person trained and educated in a profession, sometimes at the initiative of the employer but also through voluntary attendance at conferences, workshops, seminars, or enrollment in postgraduate courses, particularly important in professions that have a rapidly changing knowledge base" p 569. There is no doubt that the field of librarianship is experiencing rapid changes. These changes have been mostly attributed to advancement in Information Technology (IT) (Majid, 2004; Sridhar, n. d.). The adoption of IT in most libraries has led to major changes in the areas of equipment, staffing, collections and services (Troll, 2001). These changes according to Youngok (2006) and Mêgnigbêto (2007) demand the acquisitions of new skills and competencies in order to meet the information needs of users and fulfill the mission of libraries. Indeed, ACRL statement on professional development (2000) affirms that professional development is essential for academic librarians to keep current with skills, knowledge, and competencies in rapidly changing times. The purpose of continuing professional development activities, therefore, is to fill-in the knowledge gaps between formal education and the needs of the professional practice (Majid, 2004). Within the Nigerian context, Oduwole (2005) and Igun (2006) note that the adoption of IT into libraries has been greeted by dearth of experienced library staff. This is in line with Chiware (2007) as cited by Fadehan \& Ali (2010) who maintains that the skills for e-resources development and management are still lacking in African universities. The reason for this may not be farfetched. Even though library schools in Nigeria have started introducing aspects of IT into their curriculum, majority of the experienced librarians in most libraries completed their library education without much exposure to the practical aspects of IT. As a way of escaping from this quagmire, Akinpeju (1999) postulates that the process of training and development is a continuous one.

Role of social media in professional development: According to Meyrowitz (1997), individuals no longer need to travel and "be" in a physical location to receive information and participate in conversations or events, nor do they have to be excluded from events they cannot physically attend ( $p$. 44). Lin (2002) also states that online social networks enhance the flow of information hence the individuals in online networks gain information about opportunities and choices that otherwise would not be available for them. This has been made possible through social media which enables interaction in virtual space without the constraints of time and geographic boundary. Emery (2008) notes that Librarians who participate in social media are likely to know what their colleagues in other institutions are working on and can easily identify services and applications that can be localized more readily to their own work environment. In other words, experiences acquired from colleagues at an international level, can be shared at the local level which then feeds into service development at a local level. Indeed, Oberg (2002) notes that without new experiences, we tend to stagnate and become brittle. Librarians must therefore look out for new ways of providing services in the technological age. As noted by Atulomah \& Onuoha (2011) librarians now take advantage of the opportunities offered by Web 2.0 applications to improve their skills and offer better services to users. Allen (2010) reports the findings of 
a study on librarians' attitude towards social media in European libraries. The findings affirm that the top social media applications used by respondents in the survey were Facebook (63\% of respondents), blogging (55\%), widgets such as RSS (46\%) and microblogging (also 46\%). In a similar study on the perceptions, awareness and acceptance of Library 2.0 applications among librarians at the International Islamic University of Malaysia, Mansor \& Idris (2010) found out that $97 \%$ of the respondents had read blogs. More than half (53\%) had added posts to blogs. $90 \%$ of the respondents had read entries in Wikipedia, but only $3 \%$ had added entries in Wikipedia. $30 \%$ of the respondents had used RSS feeds and $63 \%$ had participated in social networking. $47 \%$ had used pictures from Flickr and only $20 \%$ of the respondent had added pictures to Flickr. Although not restricted to librarians, the CARA group (2011) conducted a survey with the goal of examining the current role, challenges and opportunities of social media in workplace-based informal learning. Findings of the survey revealed that $98 \%$ agree that social media are changing how employees are learning and accessing information; 82\% of the respondents affirm using social media to advance their own professional skills and resources.

Learning strategies in social media: As a common feature of most social media, users can learn by subscribing to blogs and joining discussion groups based on their interest (Askanase, 2009). For those who join groups, there is the tendency to learn from people performing similar tasks and roles. Adah (2010) affirms that newsgroups and mailing lists provide a wonderful opportunity to discuss mutual concerns quickly. Content communities such as YouTube also enhance the understanding of subjects through pictures and videos. Question asking also promotes learning in social media as users can post questions directed to individuals, or the network itself. Considering the various ways by which knowledge can be exchanged using social media, Evans, Kairam \& Pirolli (2009) classified information gathering strategies into three broad categories which they term "targeted asking", "network asking" and "searching". In targeted asking, users identify specific friends or colleagues to ask for help or advice oneon-one. Network asking involves posting a question in a public venue for every member of the social network to see, while searching involves going through an existing database of content previously provided by other users, such as searching over the collection of public Twitter posts. Network asking on the other hand, they maintain, distributes the question over a wide and diverse audience which theoretically increases the likelihood of reaching an individual with the appropriate answer. The usefulness of information gathered from social media to learning is affirmed by Morris, Teevan \& Panovich (2010) whose study revealed that some relevant information gathered from online social networks very likely do not exist on search engines such as Google, and thus could not possibly be found via Google search. This they attributed to the fact that online social networks most often provide customized answers which they found to be particularly useful when seeking opinion based information. In Onuoha's (2012) study which investigated librarians use of online social networks in Nigerian university libraries, it was established that majority of the respondents (55.85\%) acquire work related information by searching through members profile information on online social network from where they gather personal information to contact members either through email, telephone call or personal visit. More than half of the study's respondents (52.59\%) join groups on social networking sites as part of their information gathering strategy. The least used information gathering strategy was found to be "network searching", as the least number of respondents (11.04\%) admitted to searching through past comments/posts or viewing members' updates as a strategy for gathering professional information.

\section{Methodology}

The survey research design was used for this study. The study population consists of 1294 registered librarians on Nigerian Library Association (NLA) online forum as at 15th October, 2012 (NLA, 2012). The use of registered members of NLA online forum was found suitable for this study as it provided an avenue to reach librarians in Nigeria irrespective of geographic boundary or place of employment. Random sampling technique by balloting was used in selecting 297 librarians as the sample for the study using the list of registered members on NLA online forum. A self designed instrument titled "social media and professional development questionnaire" was used for data collection. The questionnaire was mailed along with a letter of introduction to the email addresses of the respondents. However, respondents who opted out from the survey or whose email addresses bounced back were promptly replaced.

\section{Presentation of findings}

Out of 297 copies of the questionnaire sent out, 180 were successfully filled and returned. A total of 94 respondents $(52.22 \%)$ were male while $86(47.78 \%)$ were female. The age group of $40-49$ years had the 
highest number of respondents 58 (32.22\%) while the age group of 60 or older had the least number of respondents. Majority of the respondents 67 (37.22\%) have Masters Degree in Library and Information Studies (M.L.I.S). Some of the respondents, however, indicated that their highest academic qualification were in other areas such as MIRM, MHIM, MHR\&OB, MBA and, M.Phil. The respondents came from different sections of the library, with most of them 41 (22.78\%) coming from the cataloguing section. Some respondents (34.44\%) indicated other areas which were not listed as options such as administration, e-library and teaching.

Table 1: Demographic information of respondents

\begin{tabular}{lll}
\hline Demographic information & Frequency & Percentage \\
\hline Gender & & \\
Male & 94 & $52.22 \%$ \\
Female & 86 & $47.78 \%$ \\
Age bracket & & \\
$21-29$ & 23 & $12.78 \%$ \\
$30-39$ & 44 & $24,44 \%$ \\
$40-49$ & 58 & $32.22 \%$ \\
$50-59$ & 26 & $14.44 \%$ \\
60 or older & 15 & $8.33 \%$ \\
Skipped question & 14 & $7.78 \%$ \\
Highest academic qualification & & \\
M.L.I.S & 67 & $37.22 \%$ \\
B.L.I.S & 40 & $22.22 \%$ \\
MSC INF. & 15 & $8.33 \%$ \\
PhD & 20 & $11.11 \%$ \\
MARM & 13 & $7.22 \%$ \\
Others & 25 & $13.89 \%$ \\
Section of work & & \\
Cataloguing & 41 & $22.78 \%$ \\
Reference & 19 & $10.56 \%$ \\
Circulation & 18 & $10.00 \%$ \\
Serials & 17 & $9.44 \%$ \\
Collection/Acquisition & 13 & $7.22 \%$ \\
Bindery & 10 & $5.56 \%$ \\
Others & 62 & $34.44 \%$ \\
\hline
\end{tabular}

Social media applications used mostly for professional learning or development: Respondents were asked to indicate the social media application(s) that they use mostly for professional development. The result is shown in Fig 1.

Figure 1: Social media used mostly for professional learning or development

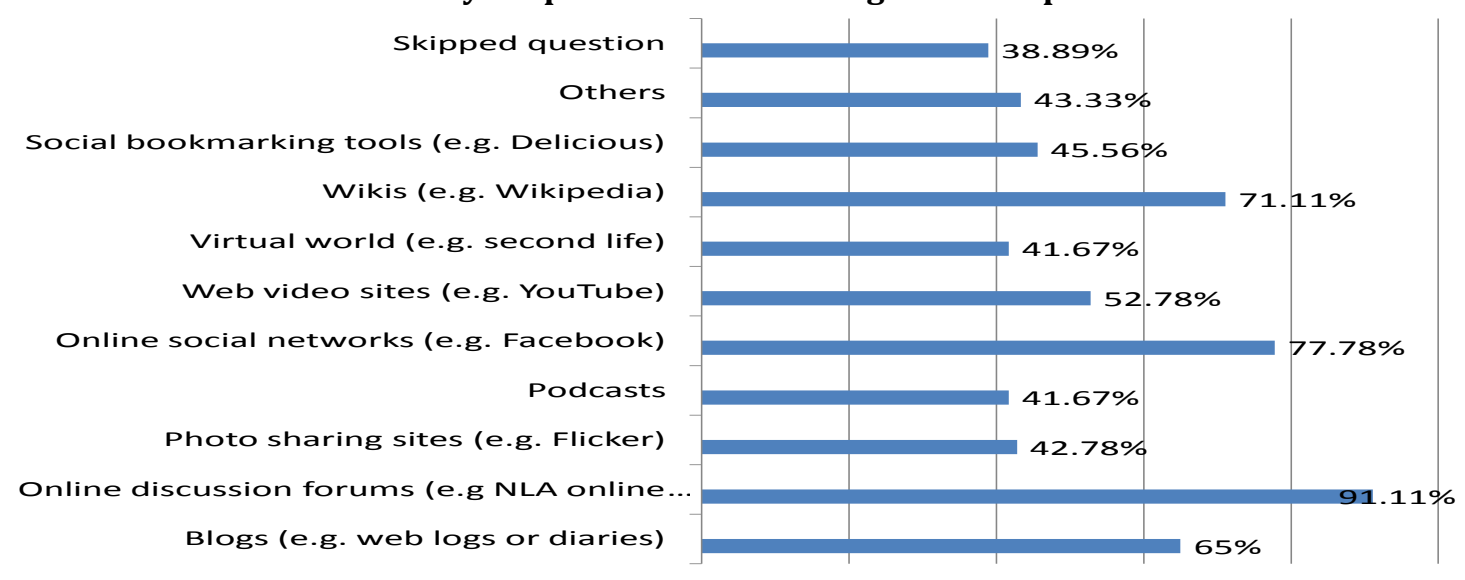

*Figures do not add up to 100 as respondents may use more than one social media application. 
Findings from Fig. 1 indicate that majority of the respondents 164 (91.11\%) use online discussion forums such as Nigerian Library Association (NLA online forum) followed closely by online social networks such as Facebook 140 (77.78\%), Wikis (e.g. Wikipedia) 128 (71.11\%) and Blogs 117 (65\%). Podcasts and Virtual world were among the least used for professional learning/development. Some of the respondents, however, also indicated using listservs.

Learning strategies using social media: Respondents were also asked to indicate their learning strategies using social media. The findings are indicated in Fig 2.

\section{Fig. 2: Learning strategies}

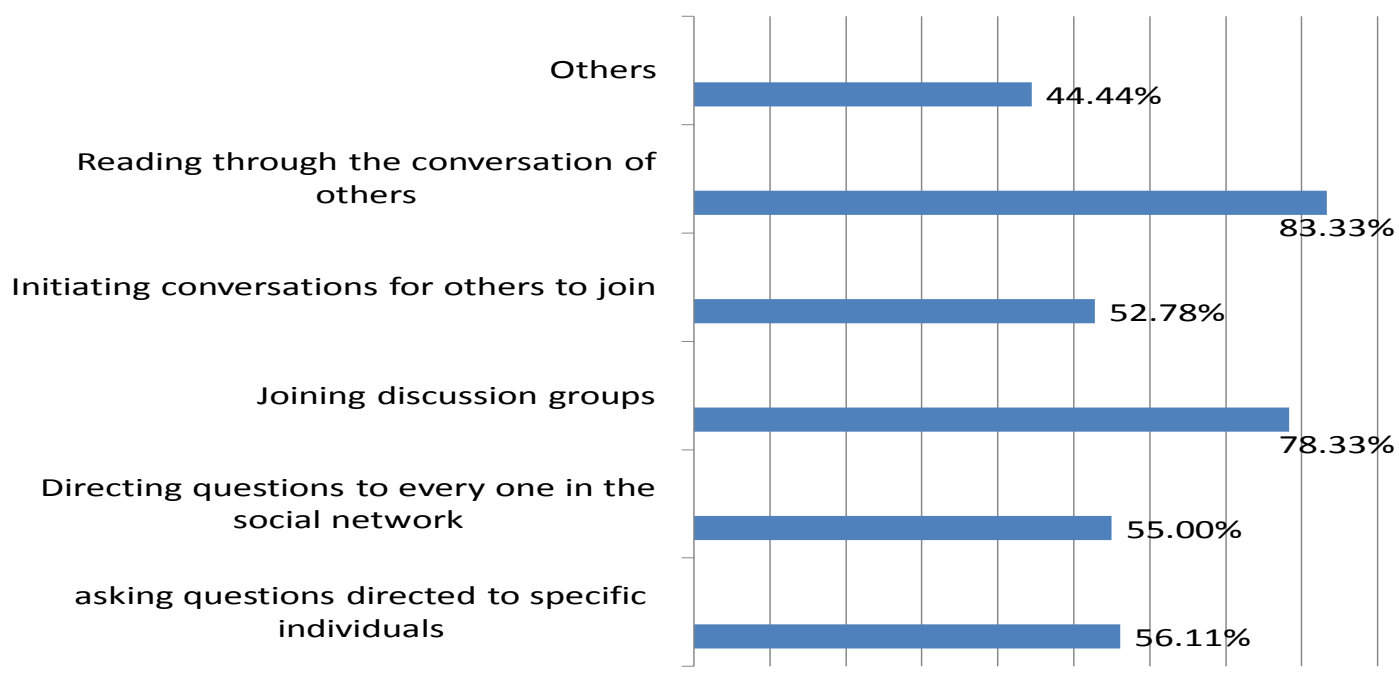

*Figures do not add up to 100 because respondents may use different learning strategies.

Majority of the respondents affirm that they learn by reading through the comments of other users 150 $(83.33 \%)$, followed closely by joining discussion groups $141(78.33 \%)$. The least used strategy was found to be initiating conversations for others to join. Some respondents, however, made comments like reading up things and learning how to use it, doing research and posting things directly to peoples' email.

Extent of satisfaction with the use of social media for professional development: In order to find out the level of satisfaction with the use of social media for professional development, respondents were asked to indicate the extent of their satisfaction. As seen in Fig. 3.

Fig. 3: Extent of satisfaction with the use of social media

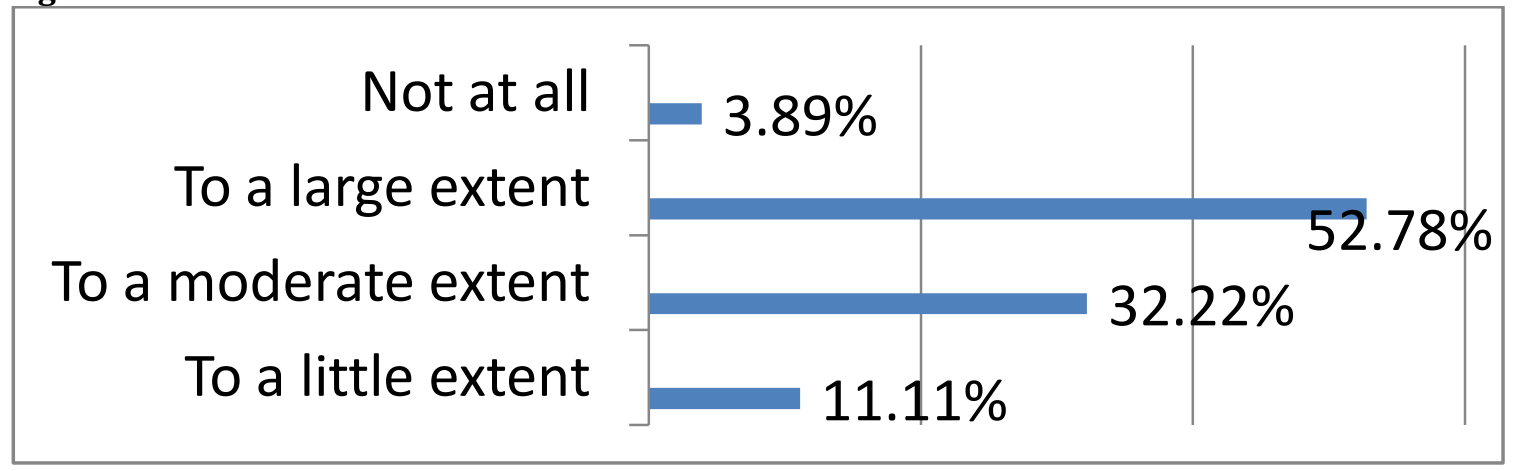

Majority of the respondents indicated satisfaction to a large extent 95(52.78\%), 58 (32.22\%) are satisfied to a moderate extent while only 27 (15\%) are either satisfied to a little extent or not satisfied at all. 
Discussion of findings: From the findings, it is obvious that librarians in Nigeria use social media for professional development. The social media applications mostly used for this purpose were found to be professional online discussion forums such as NLA online forum, online social networking sites such as Facebook and collaborative tools such as Wikipedia. The finding agrees with the assertion of Atulomah \& Onuoha (2011) that librarians now take advantage of the opportunities offered by Web 2.0 applications. It also confirms the report by Allen (2010) that applications like Facebook and Blogging are mostly used by librarians. The high use of professional online forums such as NLA online forum is not surprising as most library associations have online forums. As part of their learning strategies, librarians in Nigeria were also found to learn mostly by reading through the comments of other users and joining discussion groups. The finding is also in agreement with Askanase (2009) and Onuoha (2012) whose studies affirm that users learn by joining discussion groups. The findings indicate that simply going through the comments of other users can be a vital learning tool as it is a strategy used by majority of the respondents $150(83.33 \%)$. The study also affirmed that librarians in Nigeria are indeed satisfied with their use of social media for professional development. The finding in this case agrees with the findings of CARA group (2011) whose study revealed that $98 \%$ of the respondents agree that social media are changing how employees are learning while $81 \%$ of respondents generally feel that social media offer valuable learning opportunities for employees. The high level of satisfaction associated with the use of social media can imply to mean an attestation of its value in professional development.

\section{Conclusion}

The use of social media for professional development is no doubt a modern day phenomenon facilitated by advancement in technology. This study has established that librarians in Nigeria actively seek means of developing themselves professionally. Although various forms of social media applications exist, the study did provide valid empirical evidence to show that librarians in Nigeria use mostly online discussion forums, online social networks such as Facebook, Wikis and blogs for professional development, while social bookmarking tools, virtual world, podcasts and photo sharing sites are used minimally. The study also affirms that librarians in Nigeria mostly read through the comments of other users or join discussion groups as strategies for learning, while initiating conversations for others to join is the least used learning strategy.

Recommendation: Based on the findings of the study, the following recommendations are made:

- Librarians should make more effort to explore the inherent potentials in podcasts, social bookmarking tools, virtual life and photo-sharing sites as some of these sites may provide ideas or knowledge that could further enhance their work as librarians.

- While it is good to join groups or read through the comments of other users, librarians should not shy away from initiating conversations as that may be the quickest way of getting people to help address an immediate problem.

\section{References}

Adah, J. E. (2010). Electronic age: what can the college librarian do? Tincity Journal of Library, Archival and Information Science, 1(2), 70-73

Akinpeju, B. (1999). Educational technology and teaching - learning process in the $21^{\text {st }}$ century in Adesomowo, P. O. (Ed), Basic of Education, Lagos Triumph books publishers

Allen, K. (2010). Survey reveals attitudes towards social media in European libraries. Retrieved October 6, 2011 from http://www.infotoday.eu/Articles/Editorial/Featured-Articles/Survey-revealsattitudes-towards-social-media-in-European-libraries-72075.aspx

Askanase, D. (2009). How do you gather and process information online? Retrieved November 2, 2011 from http://www.communityorganizer20.com/2009/07/25/how-do-you-gather-and-processinformation-online/

Association of College \& Research Libraries. (2000). ACRL statement on professional development. College \& Research Libraries News, 61, 933-936.

Atulomah, B. C. (2010). Awareness of Library 2.0 and Participating in the Global Discussion among Librarians in Southwest Nigeria Universities. Retrieved December 19, 2010 from http://www.webpages.uidaho.edu/ mbolin/atulomah.htm. 
Atulomah, B. C. \& Onuoha, U. D. (2011). Harnessing collective intelligence through online social networks: a study of Librarians in private universities in Ogun State, Nigeria. Retrieved October 10, 2011 from http://www.ozelacademy.com/ojss_v4n2.pdf

Blackwell, J., Sheridan, J., Instone, K., Schwartz, D. R. \& Kogan, S. (2009). Design and adoption of social collaboration software within businesses. Proceedings of the 27th International Conference Extended Abstracts on Human Factors in Computing Systems, Boston, MA: ACM Press, 2759-2762.

CARA group. (2011). How informal learning is transforming the workplace: A pulse survey- social media's impact on informal learning. Retrieved January 3, 2013 from http://www.caracorp.com/documents/CARA_SocialMediaImpact_PulseSurveyReport.pdf

Curtis, D. (2011). What is social media? New Internet technologies are changing media. Retrieved $\begin{array}{llll}\text { February } & 27, & 2013 & \text { from }\end{array}$ http://www.uncp.edu/home/acurtis/Courses/ResourcesForCourses/SocialMediaWhatIsIt.html

Emery, J. (2008). All we do is chat: social networking for the electronic resources librarian. Journal of Electronic Resources Librarianship, 20(4), 205-209

Evans, B., Kairam, S. \& Pirolli, P. (2009). Do your friends make you smarter? An analysis of social strategies in online information seeking. Information Processing \&Management Journal, in press. Retrieved December 14, 2010 from http://brynnevans.com/papers/Do-your-friends-make-yousmarter.pdf

Ezeani, C. N. (2010). Network literacy skills of academic librarians for effective services delivery: the case of university of Nigeria library system. Proceedings of second professional summit on Information Science and Technology (PSIST) $3^{\text {rd }} 7^{\text {th }}$ May at the Nnamdi Azikiwe New Library Complex, University of Nigeria Nsukka 56-66

Fadehan, O. A. \& Ali, H. (2010). Educational Needs of Librarians in the Digital Environment: Case Studies of Selected Academic Libraries in Lagos State, Nigeria. Retrieved October 10, 2011 from http://www.webpages.uidaho.edu/ mbolin/fadehan-ali.htm

Feldman, R. (1997). Development across the lifespan. Upper Saddle River, NJ: Prentice Hall.

Gruber, A. (2008). Wired professional development: new librarians connect through the web. College \& Undergraduate Libraries, 14(4), 95-102

Igun, S. E. (2006). Human Capital for Nigerian Libraries in the 21st Century. Library Philosophy and Practice, 8(2), 1-4.

Kaplan, A. M. \& Haenlein, M. (2010). Users of the world, unite! The challenges and opportunities of Social Media. Business Horizons, 53(1), 59-6

Lin, N. (2002). Social capital: a theory of social structure and action, New York: Cambridge University Press

Lunenburg, F. C. \& Ornstein, A. C. (1996). Educational administration: Concepts and practices $2^{\text {nd }}$ edition. Belmont: Wadsworth publishing company

Macmillan Dictionary. (2013). Professional development. Retrieved February 27, 2013 from http://www.macmillandictionary.com/dictionary/british/professional-development

Majid, S. (2004). Continuing Professional Development (CPD) Activities Organized by Library and Information Study Programs in Southeast Asia. Journal of Education for Library and Information Science, 45(1), 58-70

Mansor, Y. \& Idris, S. R. A. (2010). Perceptions, awareness and acceptance of library 2.0 applications among librarians at the International Islamic University Malaysia. Retrieved Jan.10, 2013 from http://www.webology.org/2010/v7n2/a81.html

Martine, C. (2008). Facebook for professionals. Information Today, 25(4), $1 \& 48$

Mêgnigbêto, E. (2007). LIS Curriculum in French-Speaking West Africa in the Age of ICTs: The Case of Benin and Senegal. International Information and Library Review, 39(2), 158-165.

Meyrowitz, J. (1997). The separation of social space from physical place. In T. O'Sullivan \& Y. Jewkes (Eds.), The Media Studies Reader (pp. 45-52). London: Edward Arnold.

Morris, M. R., Teevan, J. \& Panovich, K. (2010). A comparison of information seeking using search engines and social networks. Retrieved March 1 , 2011 from http://people.csail.mit.edu/teevan/work/publications/posters/icwsm10.pdf

Oberg, S. (2002). Lessons in leadership: practical ideas for growing your library career. Retrieved September 9, 2010 from http://www.liscareer.com/oberg_leadership.htm

Oduwole, A. A. (2005). Information Technology Application to cataloguing in Nigerian University Libraries. The Electronic Library, 23(3), 289-291. 
Olasina, G. (2011). The use of Web 2.0 tools and social networking sites by librarians, information professionals, and other professionals in workplaces in Nigeria. Retrieved June 12, 2011 from http://unllib.unl.edu/LPP/PNLA\%20Quarterly/olasina75-3.htm

Onuoha, U. D. (2012). Use of online social networks as correlate of job performance and career success among librarians in Nigerian university libraries. PhD Dissertation submitted to the school of postgraduate studies, Babcock University

Reitz, J. M. (2004). Dictionary for library and information science. Westport, Connecticut: Libraries unlimited

Shidhar, M. S. (2012). Skills requirements of LIS professionals in the new e-world Retrieved November 6, 2012 from http://eprints.rclis.org/bitstream/10760/9436/1/J42_itskills.pdf

Troll, D. A. (2001). How and Why Libraries are changing. Retrieved April 3, 2011 from http://www.diglib.org/use/whitepaper.htm

Vaught, B. C., Hoy, F. \& Buchanan, W. W. (1985). Employee development programs: An organizational approach. Westport: Quorum books

Youngok, C. (2006). what is needed to educate future digital librarians D-Lib Magazine 12 (9), Sept. Retrieved Nov., 17, 2008 from http://www.dlib.org/dlibseptember06/choi.html. 